\title{
Quando o projeto disfarça o plano: concepções de planejamento e suas metamorfoses em Belém (PA)
}

When the project disguises the plan: conceptions of planning and its metamorphoses in the city of Belém, state of Pará

Ana Cláudia Duarte Cardoso

Taynara do Vale Gomes

Ana Carolina Campos de Melo

Luna Barros Bibas

\section{Resumo}

Uma recente iniciativa da Prefeitura Municipal de Belém de reformar a feira do Ver-o-Peso, principal símbolo do centro histórico da capital é tomada, neste artigo, como referência para discussão sobre as concepções de cidade e intervenções, conduzidas por grupos políticos locais, a partir de coalizões com o setor privado e a mídia local. Abordam-se, particularmente, as contradições presentes na tentativa de internacionalização da cidade e o caráter seletivo que o planejamento estratégico oferece, quando a esfera política não considera o ambiente urbano amazônico em sua complexidade. 0 texto alerta que seria possível criar mediações para as concepções exógenas de planejamento para propor uma base filosófica para a modernização de Belém atenta à participação popular, à festa inclusiva e à sociobiodiversidade local.

Palavras-chave: Belém; políticas públicas; cidade criativa; gentrificação; sociobiodiversidade.

\section{Abstract}

The recent initiative of the municipal government of Belém to renovate the Ver-o-Peso open market, the main symbol of the capital's historic downtown, is taken, in this paper, as a starting point to discuss conceptions of city and interventions conducted by local political groups based on coalitions with the private sector and the local media. The paper approaches, particularly, the contradictions observed in the attempt to internationalize Belém and the selective nature that strategic planning offers when the political sphere does not consider the complexity of the Amazonian urban environment. The text argues that it would be possible to create mediations for exogenous conceptions of planning in order to propose a philosophical basis for the modernization of Belém that takes into account popular participation, the inclusive party and the local socio-biodiversity.

Keywords: Belém; public policies; creative city; gentrification; socio-biodiversity. 


\section{Introdução}

Este artigo adota uma iniciativa da Prefeitura Municipal de Belém de reformar a feira do Ver-o-Peso, principal símbolo do centro histórico de Belém, como mote para discussão de concepções para a cidade, nem sempre explicitadas, mas conduzidas pelos grupos políticos no poder a partir de coalizões com segmentos do setor privado e do suporte da mídia local. Após três meses de sua divulgação, as críticas prevaleceram, e a iniciativa foi suspensa sob alegação do Prefeito de que fantasmas político-ideológicos pairavam sobre os feirantes, em alusão à resistência e à evocação de outras concepções de gestão da cidade. 0 processo teve início em 2014, a partir da abertura do edital de licitação do projeto para a feira, que foi efetivamente contratado em setembro do mesmo ano e entregue em abril de 2015. A apresentação à população foi feita no dia do aniversário de 400 anos da cidade, em 12 de janeiro de 2016, sem debate prévio. Diversas audiências foram realizadas por determinação do Ministério Público Estadual, com mobilização de vários setores da sociedade para evidenciar que, mais do que fantasmas, há desinteresse pelo diálogo e pela construção de uma pactuação coletiva a respeito de como tratar as áreas históricas e a orla da cidade.

Procura-se situar esse episódio como uma etapa de um processo mais amplo, no qual o projeto da feira seria apenas a ponta do iceberg, um elemento de um conjunto muito maior de iniciativas que há tempos procura associar a recuperação de monumentos e a criação de novos equipamentos públicos com um processo de abertura das orlas de Belém para o Rio. Isso, de acordo com as diretrizes de concepção de planejamento estratégico assumidas, nos países do Norte, de revitalização de áreas portuárias, abandonadas após a fuga de estruturas industriais para os países do Sul, e de sua transformação em espaços de entretenimento. Em que pese o sucesso econômico de experiências como as de Baltimore, Boston, Londres e Barcelona, é inegável que mesmo nesses contextos houve agravamento de desigualdades e de vulnerabilidade de grupos sociais de menor renda (Hall, 1998). A diferença de formação econômica e social entre essas cidades e Belém é enorme, e assumir que margens de rios (repletas de diversos usos e arranjos sociais) possam ser transformadas em espaços de entretenimento, em orlas espetaculares, demanda inúmeras mediações.

A concentração de monumentos e a excepcionalidade do conjunto urbanístico e arquitetônico da área histórica de Belém (assumida como metrópole desde o período Pombalino), sempre ensejaram uma expectativa de reconhecimento desse acervo como patrimônio da humanidade, alimentando projetos de inserção da cidade nas rotas do turismo nacional e internacional. Muitas entregas foram feitas pela equipe do governo estadual, durante os primeiros 12 anos no poder sob essa diretriz, com foco no consumo, tais como a Estação das Docas (2000), o Complexo Feliz Lusitânia (2002) e o Parque Mangal das Garças (2005), ao mesmo tempo que a Prefeitura Municipal de Belém, no decorrer de 8 anos de gestão de oposição a essa equipe de governo, desenvolveu um plano estratégico para a orla de Belém com ênfase na criação de novos espaços públicos (concurso público para projeto e reforma de Ver-o-Peso, urbanização da área do Ver-o-Rio, urbanização da orla de Icoaraci). Apesar da concorrência 
entre níveis do setor público, a área histórica foi prioritariamente tratada pelo viés da preservação de suas estruturas físicas e da restauração de edifícios históricos, representativos da memória coletiva e de forte apelo simbólico e estético, mas ainda alienados do acúmulo de práticas sociais e culturais do lugar e dos processos globais a que as cidades estão sujeitas e, particularmente, do modo como Belém assimilou as transformações ocorridas na Amazônia desde os anos 1960. Em que pese a motivação econômica de alavancar o turismo, na escala local, o debate sobre possíveis antídotos para processos de gentrificação, alienação social e museificação foi deixado em segundo plano.

Após um intervalo de 4 anos, em 2011 a mesma equipe retorna ao Governo Estadual, dessa vez com total alinhamento político com a equipe da Prefeitura de Belém a partir de 2013, o que favoreceu a retomada da antiga proposta de projetar Belém no cenário internacional, agora não mais baseada na revitalização de estruturas históricas, mas no potencial de biodiversidade, sustentabilidade e turismo, este último fortemente apoiado na cultura, gastronomia, música e saberes populares e ancorado em Belém, demonstrando inspiração no ideário da sociedade criativa, difundido nas últimas décadas, por economistas norte-americanos e canadenses (Florida, 2010 e Glaser, 2011).

Uma mistura dessas duas "escolas" fundamenta as propostas para a capital - planejamento estratégico catalão e sociedades criativas -, viabilizadas pela euforia do alinhamento político dos dois níveis da administração pública e pela simpatia de setores privados pelos temas, reeditou os antigos projetos de intervenção tendo em vista o aumento do volume de turistas internacionais, acentuando, contudo, contradições entre as estratégias de invisibilizar segmentos da população que vivem ou trabalham nas áreas-alvo da espetacularização da cidade e da necessidade de explorar cultura e tradição e mesmo marcas e símbolos, construídos através de séculos de trabalho pelas pessoas que agora representam o ambiente hostil e selvagem, a decadência urbana, o perigo e a desordem, identificados e ainda não controlados, com forte risco de "jogar a água com a criança junto".

Em 29 de agosto de 2015, uma série de reportagens foi veiculada na mídia impressa, televisiva e digital local, sobre a orla da cidade, com a manchete "Favelização toma conta da orla de Belém" (ver Figura 1), destacando o quanto portos clandestinos e cemitérios de barcos degradam a orla e estimulam construções ilegais, bloqueando o contato da cidade com o rio, na contramão das providências, em curso no País, de desocupação de áreas de preservação permanente, citando o exemplo das demolições ocorridas na orla do Lago Paranoá, em Brasília.

0 maior destaque foi dado para a área do Porto do Sal - repleta de estivas, palafitas, oficinas, estaleiros e inúmeras embarcações, com usos e formas de apropriação orientados por uma população ribeirinha, que historicamente reconhece a orla e o rio como espaços de produção e reprodução da vida - completamente diversa da ocupação recente (e criminosa) de Área de Preservação Permanente da orla do Paranoá.

A localização desse porto popular pode explicar a atenção especial para essa fração da orla de Belém. 0 Porto do Sal foi construído numa época em que o Ver-o-Peso era dominado pela elite comercial da cidade, na divisa entre 
Figura 1 - Capa do Jornal O liberal sobre a precariedade da orla de Belém

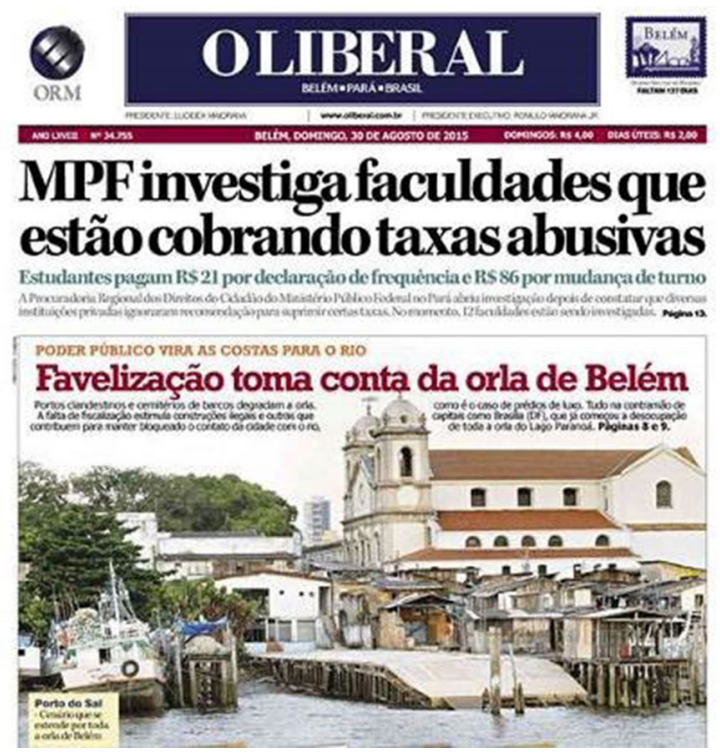

Fonte: http://www.ormnews.com.br/oliberal.

a orla urbanizada e repleta de monumentos históricos da Baía do Guajará e a orla do rio Guamá ocupada por usos industriais regionais, pequenos portos e palafitas, mais precisamente entre o complexo Feliz Lusitânia, o Mangal das Garças e o Portal da Amazônia. 0 Portal consiste em aterro realizado pela Prefeitura Municipal de Belém para implantação de uma via beira-rio que, associada a uma ação de macrodrenagem na bacia da Estrada Nova, conectará a área histórica à cidade universitária da Universidade Federal do Pará, a partir de onde seria possível sair da cidade por eixos que há vinte anos estão em processo de duplicação e/ ou extensão. 0 Porto do Sal é um espaço popular, com usos genuínos, mas de população não controlada o suficiente para viabilizar a completa conexão entre o Conjunto Feliz Lusitânia e o Mangal das Garças (já apoiado por hotéis de charme) e o Portal da Amazônia.

Em outubro de 2015, o Pavilhão do Brasil na ExpoMilão, realizada na Itália sob o tema "Alimentado o mundo com soluções", contou com a culinária paraense como estrela da festa. Foram 20 milhões de visitas e auditórios lotados com audiência interessada em frutas, ervas e pratos típicos do Pará. Como desdobramento desse evento, o Governo do Pará e a Prefeitura Municipal de Belém promoveram os "Diálogos Gastronômicos", com a presença de chefs de renome internacional e, no decorrer do evento, foi apresentado o projeto do Centro Global de Gastronomia e Biodiversidade da Amazônia. Essa notícia ${ }^{1}$ foi veiculada pela mídia nacional, 
informando que o complexo Feliz Lusitânia (onde são localizados o Forte do Castelo, a Catedral da cidade e o conjunto jesuítico composto pelo arcebispado e pela Igreja de Santo Alexandre) abrigaria o centro de gastronomia, a escola de gastronomia, o laboratório de alimentos, o barco cozinha, o museu e restaurantes.

Em 11 de dezembro de 2015, Belém recebeu título de Cidade Criativa da Gastronomia, concedido pela Unesco, ${ }^{2}$ conquista de uma articulação entre Governo Estadual, Prefeitura e instituições que promovem e divulgam a gastronomia paraense, defensores de gastronomia sustentável e entidades envolvidas com empreendedorismo regional. Nesse mesmo ano, foram abertos os boxes gourmet no Mercado de Carne, edifício histórico restaurado e entregue à população em 2011, que marcam a tendência de mudança de uso desses equipamentos (mercados de carne, mercado de peixe e feira do Ver-o-Peso) manifesta na concepção do projeto da feira, apresentado em janeiro de 2016, e nas novas regulamentações sobre a criação do "Espaço Gastronômico Cultural da Amazônia" (decreto municipal n. 84.986/2016) e sobre operação de feiras e mercados em Belém (decreto municipal n. 84.927/2016). Estas últimas alteram as formas de concessão e justificam a mudança das estruturas físicas dos boxes com base nas exigências de condicionamento dos alimentos estabelecidas pela Anvisa. Vale ressaltar que, além de dificultar a adequação dos antigos feirantes, as novas regulamentações rompem com o modus operandi já estabelecido em feiras e mercados da cidade, de exploração dos boxes por famílias há gerações. Espacialmente, novas soluções tecnológicas induzem mudanças no modo de operação na feira. Por exemplo, a forma como o box de cada comerciante era disposta permitia a ampla visibilidade do espaço de comercialização e, com isso, favorecia o controle visual de vendedores e consumidores, dificultando a prática de atividades ilícitas no local (tráfico de drogas, furtos, etc.) e permitindo que os feirantes negociassem produtos rapidamente para atender a um freguês. Esse arranjo espacial vem mudando e, na nova proposta, seria completamente eliminado.

Por outro lado, as novas propostas incorporam estruturas próximas, algumas já recuperadas como o Palacete Pinho que, após a restauração, em 2011, não teve destinação de uso, e também reclamam a revisão dos espaços tradicionalmente ocupados por práticas populares, como a Feira do Açaí, o Porto do Sal, os galpões abandonados do Porto (ampliação da Estação das Docas) ${ }^{3}$ e os edifícios históricos da Avenida Boulevard Castilhos França, que dá acesso a muitos desses equipamentos. De um modo geral, observa-se que alguns setores da sociedade contam com acesso privilegiado à informação, o que tem viabilizado a aquisição de imóveis que necessitam de obras de restauração por grupos seletos de empresários, visando a sua adaptação para acomodação de visitantes (pousadas e albergues), restaurantes e bares, que, do ponto de vista físico, tendem a não realizar o restauro, mas a criar cenários e, do ponto de vista social, tendem a promover a gentrificação da área, caindo na contradição de remover os elementos que compuseram a paisagem sociocultural responsável pela ascensão de Belém como um destino turístico. As Figuras 2 e 3 mostram algumas das áreas/estruturas citadas para melhor compreensão do entrelaçamento existente entre espaços monumentais e de valor históricos e espaços populares na 
Figura 2 - Tipos de usos da orla de Belém

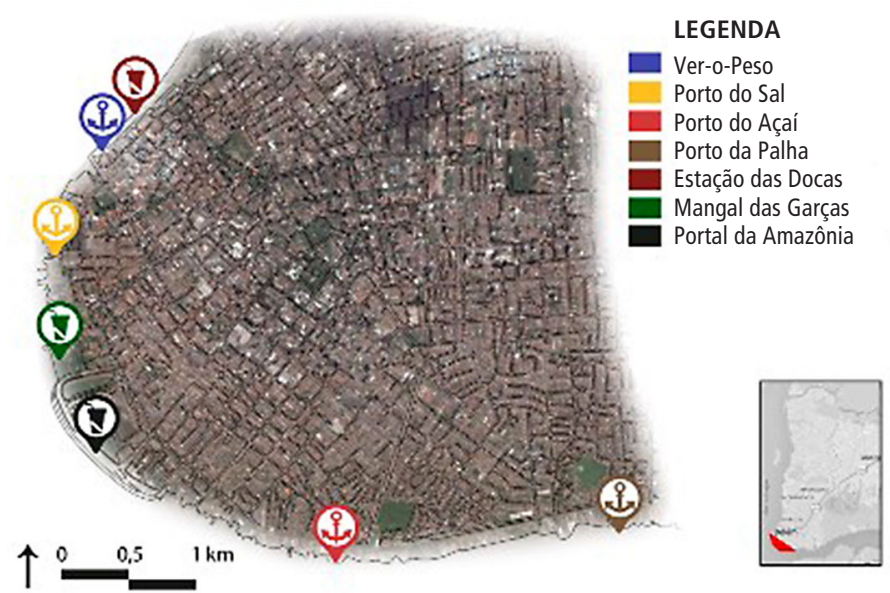

Fonte: Figura elaborada por Luna Bilbas, a partir de imagem do Google Earth, 2016.

Figura 3 - Projetos na orla do centro histórico

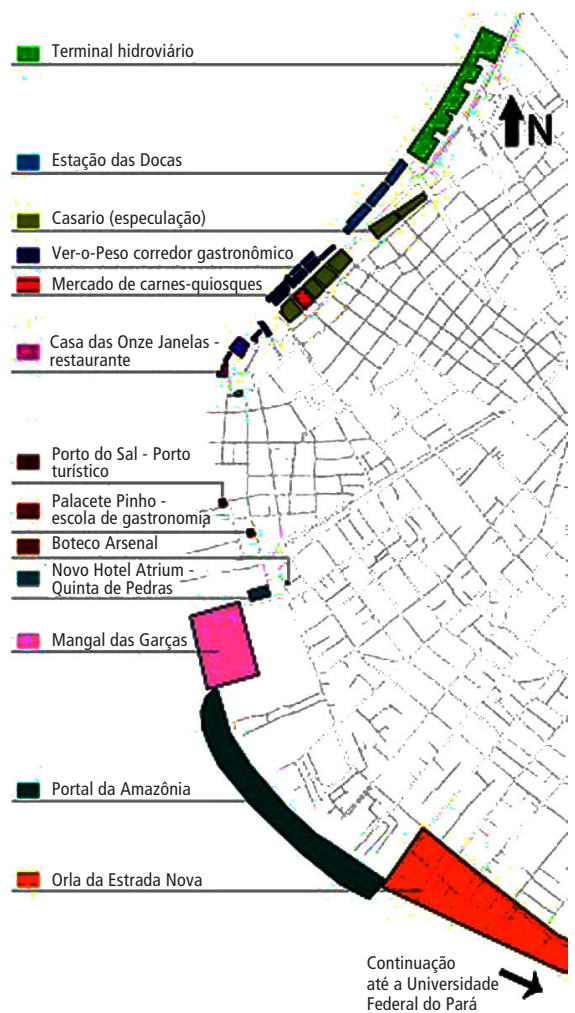

Fonte: Figura elaborada por Luna Bilbas, a partir de imagem do Google Earth, 2016. 
orla do centro histórico de Belém, e que agora extrapola para a orla do Rio Guamá, tradicionalmente ocupada por população de baixa renda e por usos produtivos. ${ }^{4}$

\section{Revelando as distorções das fórmulas externas}

Vinte anos após a conferência da ONU Habitat, em 1996, quando Borja e Castells prepararam um documento sobre como construir o protagonismo político de cidades, com base em exemplos de cidades europeias, norte-americanas, asiáticas e sul-americanas consideradas bem-sucedidas no enfrentamento da crise econômica iniciada nos anos 1970, seus princípios fundamentam a concepção de cidade que grupos da elite política e econômica local esperam tornar hegemônica em Belém. A localização do mercado em área histórica, constituída por conjuntos de praças, palácios, igrejas monumentais, parque botânico, museus e espaços de consumo adaptados em estruturas históricas (antigos galpões portuários), tem contribuído para a terceira colocação da cidade no ranking dos destinos turísticos nacionais. Até a primeira metade do século XIX, o atual centro histórico abrangia toda a cidade e abrigava espaços populares na orla do Guamá e as elites na orla da Baía do Guajará. A Figura 4 ilustra a distribuição de monumentos (palácios, equipamentos públicos, igrejas, conventos, um conjunto de praças monumentais, algumas viabilizadas por aterros de várzeas e sobre a Baía do Guajará) e destaca os símbolos do poder histórico da elite sobre esse território.
Diante do acervo arquitetônico e da sociobiodiversidade existente em Belém, são inegáveis a vocação e a pertinência da proposta de torná-la um destino turístico, sob a perspectiva da busca de fortalecimento da competitividade das cidades no cenário internacional e, sobretudo, como possibilidade de valorização e sofisticação do saber tradicional e dos recursos da floresta (Silva, 2015). Contudo aspectos relacionados com o exercício da liderança política promotora do projeto estratégico (o prefeito carismático $)^{5}$ ou com as possíveis inovações administrativas e práticas de governança comprometidas com a diversidade e cooperação social são fundamentais para a discussão de uma concepção do gênero para Belém, para a construção de mediações necessárias entre as recomendações dos autores catalães e a sua assimilação no contexto paraense, conforme exposto a seguir.

Borja e Castells (1996) abordam contextos metropolitanos, nos quais há concorrência de diversas cores políticas (prefeituras dos municípios constituintes) e necessidade de ação em diversas áreas de política pública pelo governo local (gestão urbanística, economia, segurança, seguridade social), que no caso de Belém estão longe de serem equacionadas. A expectativa de melhorar a atuação do governo local através do fomento de parcerias público-privadas em situações de disputa com governos nacional e regional, também é relativizada no caso de Belém, metrópole terciária que sempre sofreu forte impacto das ações federais.

Outra inovação política proposta foi a construção de uma identidade coletiva, que Vainer (1999) traduz como patriotismo, manifesta em termos concretos na adoção 
Figura 4 - Mapa do centro histórico de Belém,

com a marcação de praças, palácios, igrejas.

Ao lado, dois dos principais pontos turísticos da capital de Belém:

o Teatro da Paz e a Praça do Relógio

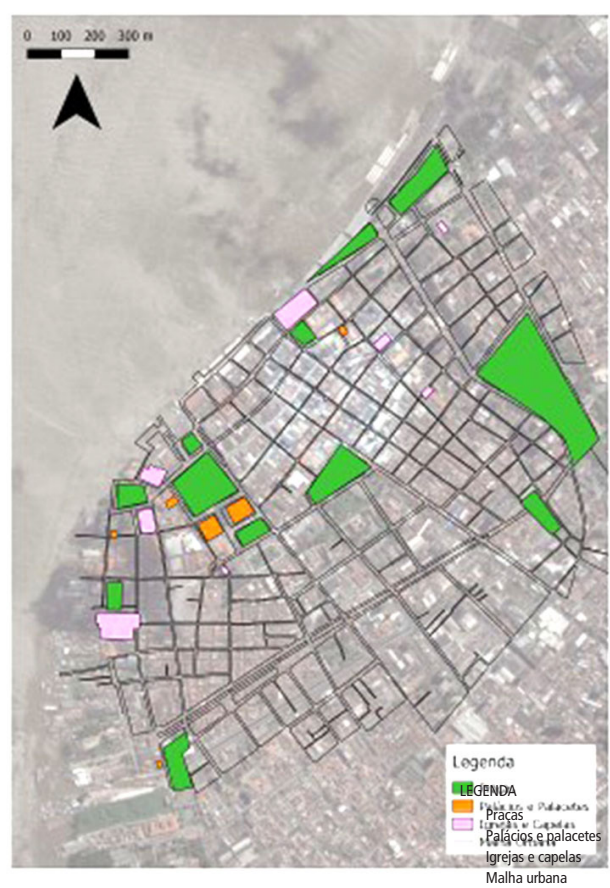

Fonte: Elaborado por Luna Bibas a partir de imagens do Google Earth, 2016.

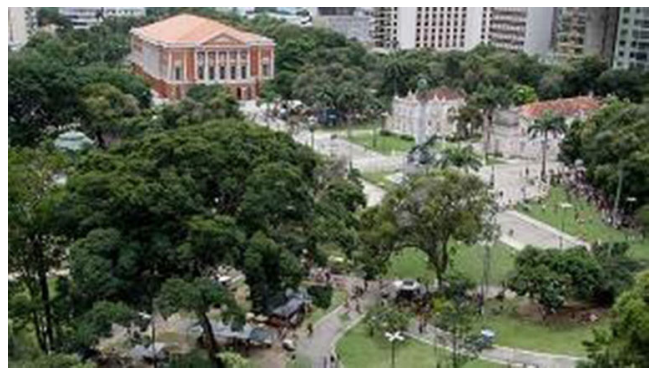

Fonte: http://noticias.orm.com.br/praçadarepublica

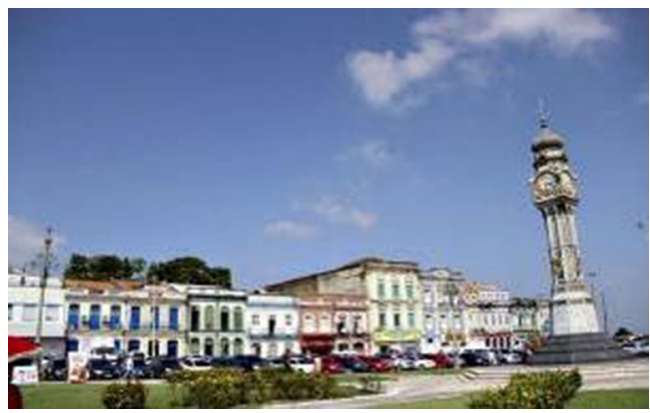

Fonte: http://www.diarioonline.com.br/noticias/praçadorelogio

populações de risco, combate de diversas formas de racismo, discriminação social, étnica ou religiosa, xenofobia, etc. (Borja e Castells, 1996), de sucesso discutível mesmo nos países do Norte, e que, no caso brasileiro, gerou toda uma literatura sobre a espetacularização de cidades que sediaram os eventos internacionais recentes no País, abordando o impacto sobre a população local das intervenções públicas e privadas realizadas de modo seletivo para alavancar o turismo. 
No caso do projeto em tela, observa-se que não há tentativa de integração de população marginalizada ou excluída, mas de cooptação do habitante por uma plataforma de cidade importada de um contexto industrial (ou a ele adaptada), voltada para o mercado internacional, com apropriação da diversidade de sabores, aromas, sons, desenvolvida e difundida por séculos através da sociobiodiversidade local, que, ao fim e ao cabo, finda na exclusão do habitante original por força da gentrificação, como foi o caso em tantos outros casos brasileiros (Recife, Salvador, Rio de Janeiro).

Os autores catalães recomendam também ações que articulem produção de habitação, geração de emprego e renda, integração cultural, articulação entre centro e periferia e ação estatal em áreas estratégicas de mobilidade, comunicações, inclusão digital, para fortalecimento da cidadania (Borja e Castells, 1996), e não há destaque para esses elementos na concepção estratégica em tela para Belém, nem indício de fortalecimento da capacidade de planejamento municipal, ponto-chave para que haja alguma capacidade de protagonismo do poder público municipal na condução das transformações desencadeadas pelos investimentos oficiais. Nesse aspecto, deve-se esclarecer que as ações de planejamento dirigidas à cidade são historicamente setoriais e de caráter incremental. 0 Quadro 1 ilustra a desarticulação histórica entre políticas de preservação, planejamento setorial de transporte, saneamento e habitação. Iniciativas da gestão

\title{
Quadro 1 - Sumário da prática desarticulada de intervenções setoriais em Belém e suas implicações para a gestão do centro histórico
}

\begin{abstract}
O Centro Histórico de Belém passou por inúmeros aterros e intervenções relacionadas aos rios e várzeas internas. 0 primeiro aterro aconteceu na metade do século XIX, e deu origem à praça em frente ao Palácio da Prefeitura e à Doca do Ver-o-Peso. Na virada do século XX o igarapé do Reduto foi canalizado e a doca do Reduto construída, esta última fechada poucos anos depois com a construção do Porto de Belém. Nos anos 1970 uma grande macrodrenagem realizada pelo governo federal viabilizou a construção da Av. Visconde de Souza Franco, que delimita a área protegida como entorno do centro histórico. Nos anos 1980 a Prefeitura Municipal de Belém e o Governo do Estado do Pará tomaram empréstimo no Banco Mundial para realizar grande ação de macrodrenagem na Bacia do Una, distante do Centro Histórico, mas cuja experiência manteve a visão setorial histórica do saneamento e não previu controle de transformação de uso e ocupação do solo nas áreas afetadas. Novo contrato com o Banco Mundial foi assinado em 2007, e operado nos mesmos termos, para a macrodrenagem da Bacia da Estrada Nova, adjacente ao Centro Histórico, ação que ainda está em andamento e é casada com a construção do aterro do Portal da Amazônia, entregue em 2012. Cada ação foi implementada de forma desarticulada em relação à política de gestão do Centro Histórico, que é tratada como uma zona especial pela Lei Complementar n. 2/1999 que incorporou a regulação estabelecida por lei específica (Lei n. 7.709/1994), que tombou o Centro Histórico, delimitou sua área de entorno e estabeleceu incentivos fiscais para a preservação de seus bens imóveis. 0 Plano Diretor de Transporte Urbano prevê articulações globais mas não detalha soluções específicas para o Centro Histórico. Da mesma forma os Planos de Saneamento e Habitação não contam com escalas de atuação que contemplem o Centro Histórico. Assim foram constituídas lacunas que facilitam a atuação a partir de projetos, que independem das premissas das políticas urbanas ou instrumentos de gestão em vigor
\end{abstract}


municipal na última década procuraram abordar as orlas da cidade de forma sistêmica, mas não foram consolidadas como um instrumento de gestão (Belém, 2004). Apesar disso, a vitalidade da região sempre foi mantida, dada a localização estratégica para os segmentos populares e ribeirinhos, pouco exigentes quanto à modernização de infraestrutura de portos, feiras e espaços em geral.

A continuidade de gestão (reeleição, extensão de mandato) não tem sido um problema, nem o alinhamento político de diferentes níveis de governo, e talvez por isso pouco esforço seja feito para potencializar o diálogo com a população e construir processos de modo coletivo. A gestão local não inova ou aproveita novas tecnologias para potencializar os canais de comunicação interna, na mesma proporção que investe nas negociações técnicas e comerciais voltadas para a articulação com redes internacionais (eventos e voos regulares internacionais). Existem assimetrias de poder na sociedade que inviabilizam a ampla discussão democrática e a construção de um plano estratégico efetivo e viável, que considere e potencialize o potencial do mercado interno.

Por vezes, ações de recuperação são fundamentadas no valor histórico da edificação e não contam com uma proposta firme de uso que articule a intervenção urbanística; noutros casos a sofisticação excessiva cria espaços de consumo que tendem a gerar exclusão social e "disneyficação" (espaços controlados para turistas).

As recomendações do documento elaborado pelos catalães, em 1996, são compreensíveis a partir do contexto que o gerou. Iniciativas de flexibilização de práticas clássicas de planejamento são plausíveis em contextos em que houve acúmulo de investimentos no decorrer de décadas e em que muito das provisões para suporte à vida já tinham sido garantidos, e a administração pública está preparada para atuar de forma inteligente em prol do interesse coletivo.

0 discurso da "cidade criativa" também foi assumido como slogan publicitário de legitimação das intervenções estratégicas em andamento no centro histórico de Belém. É interessante recuperar que o conceito de cidades criativas, popularizado por Richard Florida (2010), sugere três pilares básicos (3 T's) para construção de uma economia urbana dinâmica: tecnologia, talento e tolerância. Para o autor, estes são conceitos-chave para promover o desenvolvimento criativo e inovador, apoiado numa sociedade culturalmente tolerante e diversa. Essa abordagem enxerga o ambiente urbano como nó gerador de energia criativa e produtiva e suas especificidades como elementos potenciais para dinamização da economia local e regional. Segundo Furtado e Alves (2012), a combinação entre cidades e criatividade representa uma estratégia poderosa para a reutilização dos ativos urbanos (sociais, culturais, naturais) em benefício da sua população.

No entanto, apesar dos fundamentos políticos e da perspectiva progressista do conceito, alguns autores têm questionado as tensões presentes entre a forma como as cidades criativas são concebidas nos países do Norte e o que elas realmente se tornam quando o discurso é colocado em prática, especialmente no hemisfério Sul (Pratt, 2010 e Mendes, 2012). Em muitos casos, a implantação de planos estratégicos com esse enfoque resultou em verdadeiros retrocessos sociais e impactou negativamente os espaços de intervenção e seus entornos, na 
medida em que renovou estruturas e implantou usos que diferenciam áreas urbanas sob a perspectiva do setor imobiliário.

A cidade criativa emerge como possibilidade de recomeço para as cidades, após a flexibilização produtiva e a desindustrialização generalizada de grandes centros urbanos do mundo capitalista, na década de 1970 (Harvey, 2011). Num contexto de acirramento da competição interurbana e de ascensão do planejamento estratégico e empresarial, as cidades passaram a buscar novas alternativas para atração e reprodução do capital. No entanto, se, de um lado, a abordagem de Richard Florida enfatiza a relação entre cidade, criatividade e inovação como estratégia para promover o crescimento econômico e a vitalidade urbana e a elevação do bem-estar da vida de seus habitantes; de outro, existe também nessa vertente a expectativa de tornar a cidade objeto de especulação e de orientar as ações de renovação urbana em favor do mercado. Essa dinâmica se reproduz de forma mais perversa em países periféricos, pois nesses contextos os espaços interessantes para o setor imobiliário são mais restritos, criando a necessidade de abertura de novas fronteiras. No caso de Belém, o centro histórico surge como uma fronteira de acumulação, na medida em que os novos investimentos são capturados rapidamente pelo setor imobiliário. Embora essa resposta possa combinar temporariamente os novos usos (hotéis, bares, restaurantes, museus) à diversidade e à vitalidade da dinâmica sociocultural já existente, é muito provável que o resultado final redunde num processo de gentrificação e homogeneização do espaço, assim como é sintomática a destruição criativa (fenômeno explicado por Shumpeter, 1988) das estruturas populares e tradicionais (feira, porto, estivas) que hoje dão sentido à originalidade do lugar. É digno de nota que a crise que motivou a formulação da cidade criativa nos países do Norte também transformou a própria cidade em objeto de acumulação, de tal modo que as áreas requalificadas são facilmente incorporadas como fronteira de expansão do capital pelo setor imobiliário, ampliando as desigualdades socioespaciais históricas.

Além das críticas lançadas à ideia de cidade criativa, há outras nuances em questão quando se trata de transpor para a cidade periférica abordagens hegemônicas do Norte global.

Os novos usos e empreendimentos associados ao fortalecimento da identidade de cidade criativa, como os museus e os espaços culturais e gastronômicos, são traduzidos como uma intervenção estratégica em uma determinada área, que acaba se tornando representativa do todo em termos simbólicos, para efeito do processo de internacionalização. Isso converge para o caráter seletivo que o planejamento estratégico oferece. Nessa via, o potencial criativo genuinamente popular, como é o caso das práticas sociais que se manifestam no Ver-o-Peso, tende a ser apropriado pelas elites locais e usado para intensificar as assimetrias sociais.

Quando observados com mais detalhe, os desdobramentos desse processo nos países do Sul global são bastante diferentes dos seus congêneres, manifestos nos centros irradiadores do Norte. Na raiz do conceito, há um pressuposto da existência de um grande potencial de mercado consumidor, que não se aplica ao contexto de Belém. Há a exclusão deliberada de uma parcela significativa da população, que opera no âmbito da economia popular e que domina os saberes, ofícios e modos de fazer 
tradicionais articulados à base natural da região, com alta capacidade criativa e de resiliência, em oposição à forma de operar do circuito superior, como definido por Santos (1979); este último é pautado pelos impulsos externos de modernização e pelas relações que mantém fora da cidade e da região em que atua.

A proposta de requalificação do complexo do Ver-o-Peso (ver Figuras 5 e 6) apresenta vários elementos dessa fórmula: traça uma abordagem que se preocupa particularmente com as possibilidades de rentabilidade financeira e de projeção nacional e internacional da culinária local em favor de grupos empresariais e de interesses privados, desconsidera a elaboração de estratégias que promovam socialização e redistribuição dos benefícios para a coletividade e, sobretudo, para aqueles grupos sociais que, ao longo de gerações, têm sido responsáveis pela sobrevivência, reprodução e difusão das práticas coletivas e dos saberes populares e que tornam essa feira um espaço singular; uma festa dos sons, sabores, ritmos e cores que sintetiza a autenticidade da sociobiodiversidade amazônica.

Figura 5 - Atual feira do Ver-o-Peso

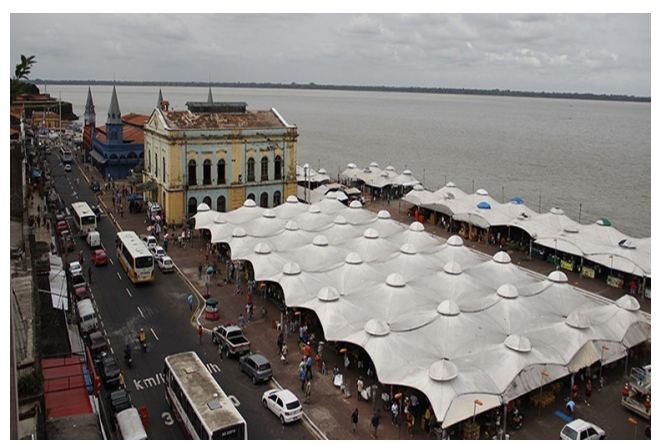

Foto: Cezar Magalhães/DOL
Há divulgação, para a população, de que os investimentos alavancarão o turismo, dinamizarão economicamente a cidade, mas a maneira como o processo tem sido conduzido (acesso à informação, tipo de empreendimentos e temas destacados) não assume as rédeas das mudanças de uso nas estratégias de apropriação do espaço público ou da valorização imobiliária e de sua captura por uma minoria que adquiriu imóveis na região, antes que o projeto dos investimentos oficiais fossem tornados públicos.

0 posicionamento filosófico assumido por ações já executadas em Belém demonstra que há duas formas bastante diversas de articulação com essas concepções internacionais sobre o protagonismo das cidades. 0 Quadro 2 contrasta duas trajetórias de ação baseadas em concepções orientadas para o consumo e o turismo e para a melhoria das condições de apropriação do espaço público e de condições de vida da população, que revelam que é inevitável embarcar nas ondas de modernização e que há a possibilidade de escolha de a quem colocá-las a serviço.

Figura 6 - Projeto de requalificação do Ver-o-Peso

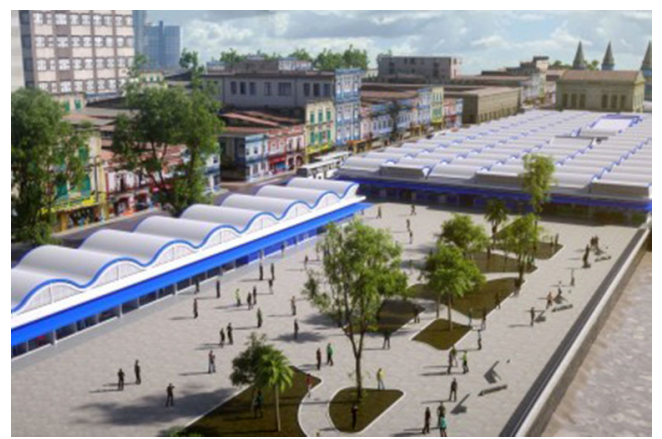

Fonte: http://avozdoxingu.com.br/page/5/ 
Quadro 2 - Estratégias de planejamento urbano empresarial e popular

\begin{tabular}{|l|}
\hline \multicolumn{1}{|c|}{ Planejamento Estratégico Empresarial } \\
\hline No planejamento estratégico empresarial os \\
projetos implantados apresentam um alto grau de \\
sofisticação e modernização que descaracteriza \\
a identidade e as práticas tradiconais do lugar. \\
Os projetos são viabilizados para atrair turistas, \\
empresários e um público específico com \\
capacidade de consumir essa nova modalidade. \\
As etapas de elaboração e implantação dos \\
projetos não apresentam diálogos abertos com \\
a população e nessa lógica se sobressai os \\
interesses privados em detrimento dos interesses \\
coletivos, acentuação a segregação social.
\end{tabular}

Figura 7 - Mangal das Garças

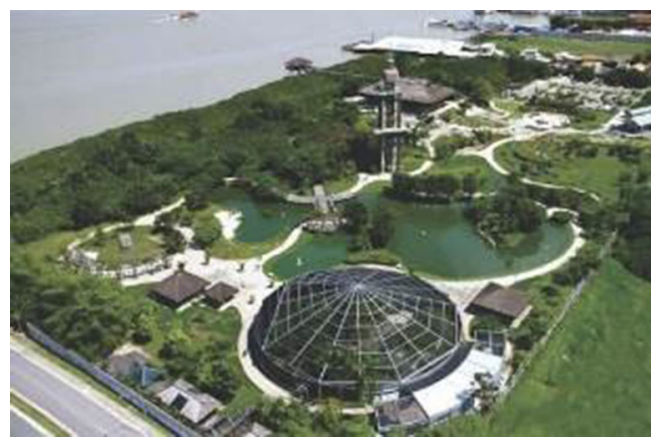

Fonte: https://beirouth.files.wordpress.com/2014/04/mangal_panoram.jpg

Figura 9 - Estação das Docas

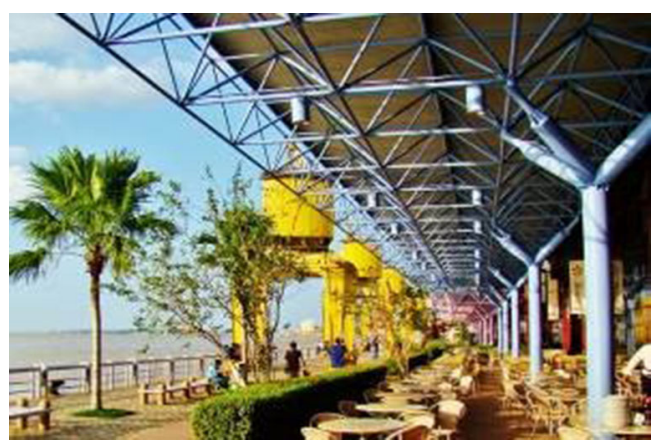

Fonte: https://c1.staticflickr.com/6218744044_732dd29e45_b. jpg

\begin{tabular}{|l|}
\hline Planejamento Estratégico Popular \\
\hline No planejamento estratégico popular os projetos \\
tem como objetivo dar visibilidade para os \\
elementos peculiares da cidade, integrando ao \\
convívio da população, ordenando as atividades \\
culturais, de lazer, de tráfego e transportes e \\
recuperando a paisagem urbana, bem como a \\
qualidade ambiental reconhecendo os espaços \\
de usos tradicionais da orla, como os portos, \\
terminais, praças, apresentando diretrizes para \\
consolidar, ampliar e requalificar esses espaços \\
partindo dos interesses coletivos e viabilizando \\
ações pontuais que geram inclusão social. \\
\hline
\end{tabular}

Figura 8 - Ver-o-Rio

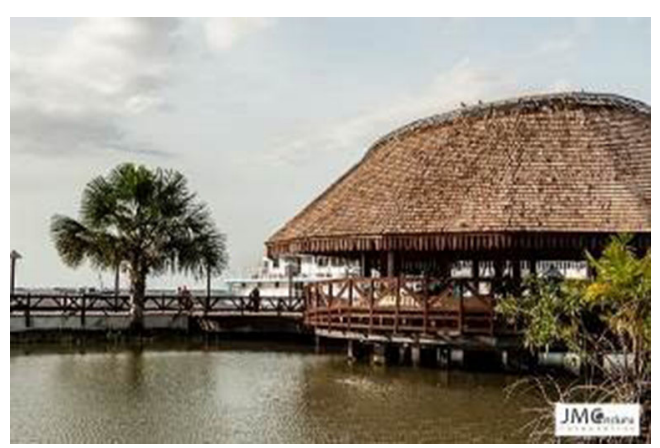

Fonte:http://1.bp.blogspot.com/-miBUMHgk8jQ/UnbYDGOEkvl/AAAAAAAAleM/WBirsInYGy8/s1600/Ver-o-rio-4.jpg

Figura 10 - Orla de Icoaraci

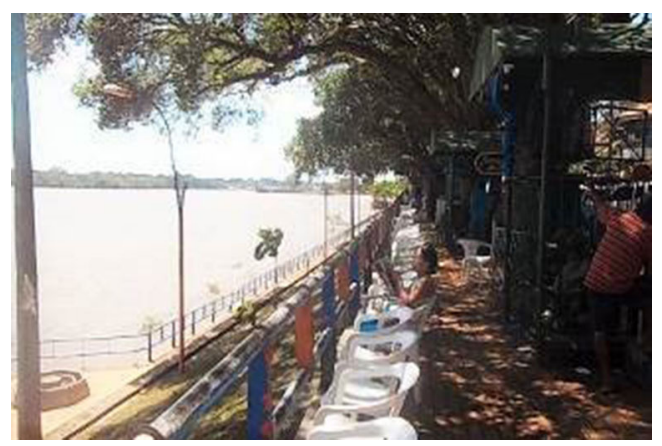

Fonte:https://media-cdn.tripadvisor.com/photo-s/09/29/3d/a7/ orla-de-icoaraci.jpg 


\begin{tabular}{|l|}
\hline \multicolumn{2}{|c|}{ Cidade Criativa Empresarial } \\
\hline Na cidade criativa empresarial está presente a \\
tecnologia e a inovação a partir da sofisticação, \\
o aspecto humano surge com o consumo e a \\
contemplação. É um capitalismo criativo, que absorve \\
as estratégias que emergem com as cidades criativas, \\
mas tem como base o desenvolvimento econômico \\
e ignora o capital humano. A cidade criativa \\
empresarial cria novas fronteiras imobiliárias a partir \\
dessas novas atrações, intensifica as assimetrias, cria \\
uma "marca" e tem o foco na geração de valor.
\end{tabular}

Figura 11 - Boteco do Arsenal

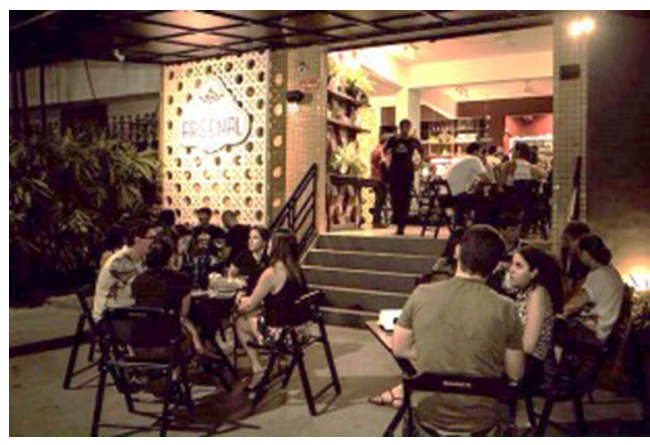

Fonte:https://www.tripadvisor.com/Boteco_Arsenal.html

Figura 13 - BoulevArte

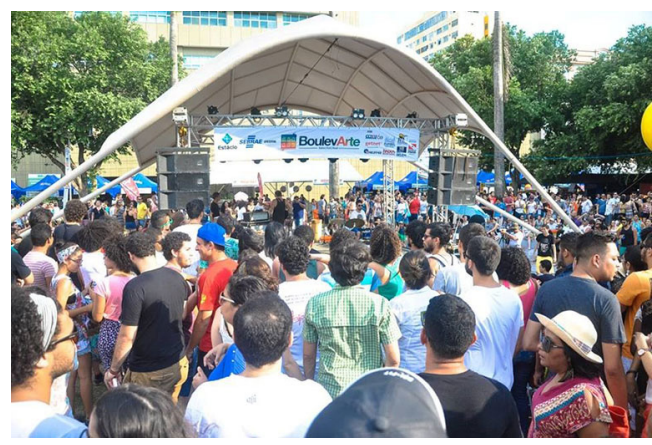

Autor: Renato Reis (2015).

\begin{tabular}{|l|}
\hline Cidade Criativa Popular \\
\hline Na cidade criativa popular encontra-se os apectos mais \\
humanos do conceito base de Florida (2010), o talento, a \\
tolerância, a diversidade, a boemia, os profissionais das áreas \\
criativas (artistas, dançarinos, músicos, cozinheiros, pintores, \\
performers) e é a partir desse contexto social que surge a \\
possiblidade de atrair essa nova economia. É um contexto \\
inclusivo, que se apropria e dá vida a determinados espaços \\
da cidade através de sons, sabores, ritmos e cores. No popular \\
os espaços passam a ter um uso coletivo, comunitário, \\
colaborativo,éum espaço queemerge a partir da criatividade. \\
\hline
\end{tabular}

Figura 12 - Bar do Rubão

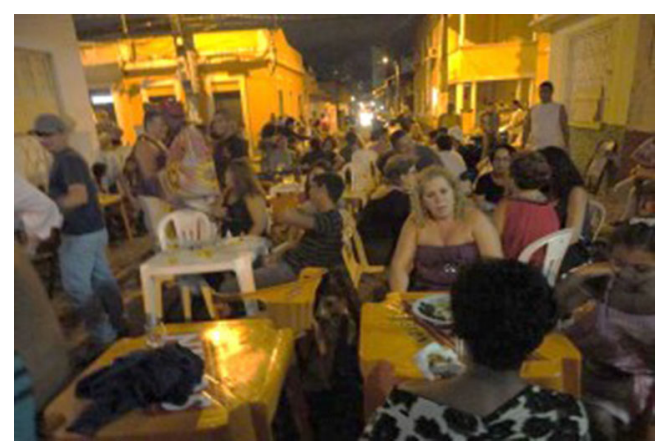

Fonte:https://imagesapt.apontador-assets.com/fit-in/640x480//bar-do-rubao.jpg

Figura 14 - Encontro Cultura na Praça das Mercês

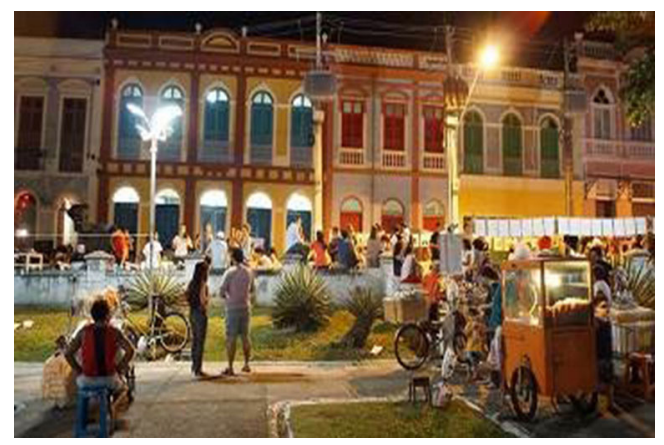

Autor: Arlem Araújo (2015). 


\section{Por uma nova base filosófica para a modernização de Belém}

0 entrelaçamento entre a base natural da região (o rio, a floresta) e o conhecimento tradicional tem sustentado as atividades econômicas nucleadas em Belém, desde a sua fundação, sobretudo aquelas ligadas à exportação de matérias-primas oriundas da floresta amazônica. A economia mercantil fortemente apoiada nas práticas extrativistas foi favorecida pela miscigenação entre europeus e índios durante o século XVIII, constituindo uma população cabocla que reteve o conhecimento da floresta, ao mesmo tempo que se se integrou à racionalidade produtiva (Costa, 2009) e que gerou o potencial criativo da capital paraense e seu vínculo com a matriz popular.

Esse processo contribuiu para que, no decorrer de quatro séculos, o Ver-o-Peso se transformasse na maior feira livre do País e nucleasse um complexo que abrange a Feira do Açaí, a Pedra do Peixe, os Mercados do Peixe e de Carne, o Solar da Beira e as Praças do Pescador e do Relógio. 0 reconhecimento do valor histórico e arquitetônico desse espaço levou ao seu tombamento e também do conjunto arquitetônico adjacente, que incorpora mais praças, palácio e o casario antigo. Os imóveis particulares têm sido mal-preservados, alguns estão em ruínas, e muito pouco avanço foi observado nas tentativas de articular políticas naquela área, aproveitando o acúmulo de infraestrutura e suas vocações econômicas, assim como as limitações de acessibilidade em relação à cidade como um todo (por exemplo habitação de interesse social, geração de renda, mobilidade).
Nos últimos anos instituições públicas recuperaram alguns imóveis (Sesc Boulevard), mas, em 2015, aumentou a procura por tais edificações pelo setor empresarial (ver Figuras 15, 16, 17 e 18).

A feira é elemento típico do ambiente urbano amazônico, que normalmente ocupa vários quarteirões no centro de qualquer cidade tradicional, nas proximidades do rio. No caso de Belém, também é o ponto de contato entre produção popular (o pescado, as frutas, a farinha, as ervas) e a empresa capitalista (cadeias de supermercado, indústrias de alimentos), graças ao crescimento do mercado interno na Região Metropolitana de Belém ocorrido nas últimas décadas (Araújo, Souza e Rodrigues, 2015).

Infelizmente, a especialização no fornecimento de matérias-primas não viabilizou a divisão social do trabalho tão necessária para a promoção de desenvolvimento em Belém ou na região. Belém nunca contou com a dinâmica de pleno emprego e a de assalariamento, típicas do contexto industrial central, embora sempre tenha havido abundância de alimento e condições de improviso para viabilizar a reprodução da vida. Essa "contradição" sempre gerou, na visão do migrante, uma interpretação de indolência por parte do caboclo, nativo e detentor do conhecimento necessário para tirar o sustento do bioma.

A instauração de uma nova ordem mundial, segundo a qual cidades dos países do Norte perderam postos de trabalho industriais, foram despoluídas, renaturalizadas, vem destacando oportunamente infraestrutura e camadas técnicas de suporte às atividades e o capital cultural e humano acumulados, como recurso para inaugurar uma era de 
Figura 15 - Complexo do Ver-o-Peso

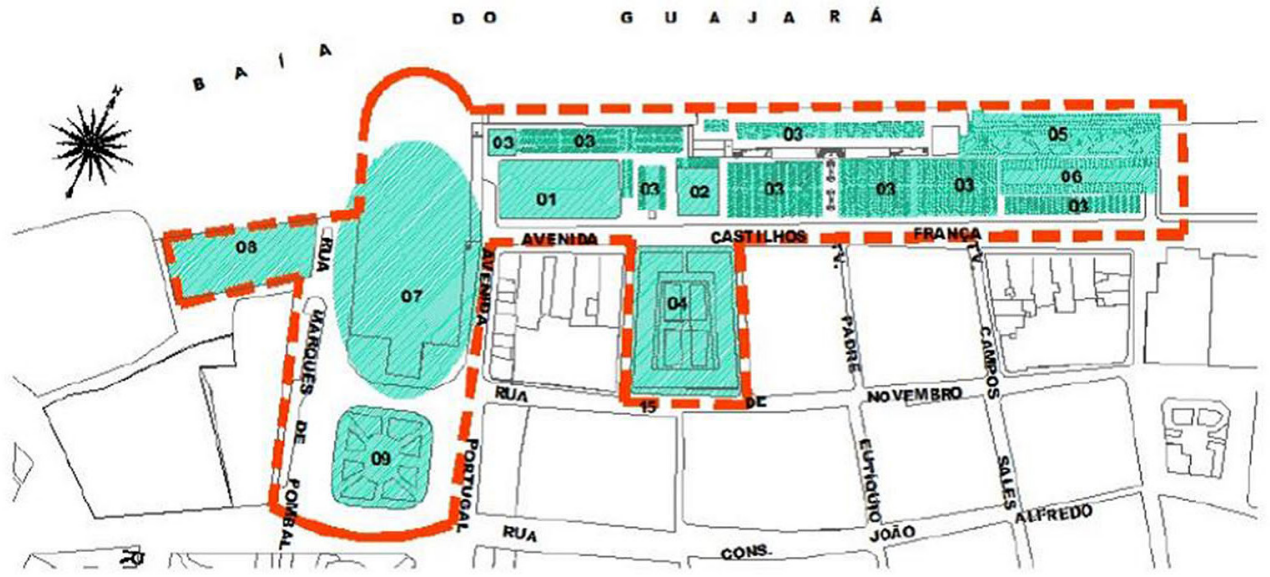

LEGENDA

01 - Mercado de Peixe

06 - Área de estacionamento

03 - Feira do Ver-o-Peso

07 - Docas

04 - Mercado de Carne

08 - Feira do Açaí

05 - Praça do Pescador

09 - Praça do Relógio

Complexo Ver-o-Peso

Elementos constituintes do Ver-o-Peso

Fonte: Carvalho, Lima e Leitão (2010).

Figura 16 - Conjunto arquitetônico e paisagístico do Ver-o-Peso

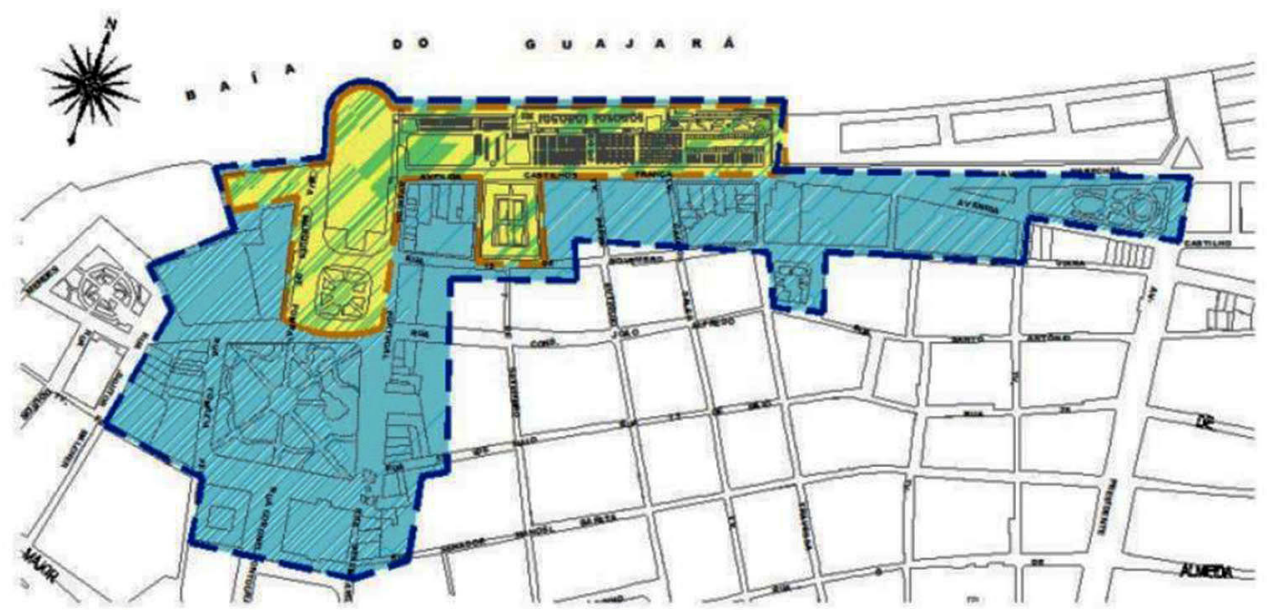
LEGENDA

Complexo Ver-o-Peso

Conjunto arquitetônico e paisagístico do Ver-o-Peso - Tombado
Sobreposição do Complexo Ver-o-Peso com o conjunto tombado

Fonte: Carvalho, Lima e Leitão (2010). 
Figura 17 - Feira do Açaí

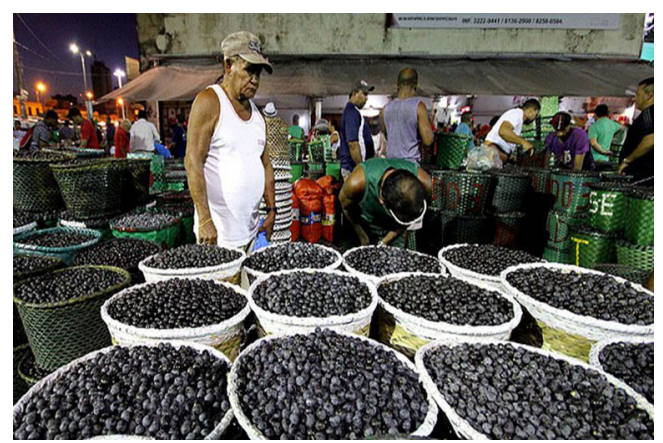

Fonte: http://www.matraqueando.com.br/feira-do-acai
Figura 18 - Pedra do Peixe

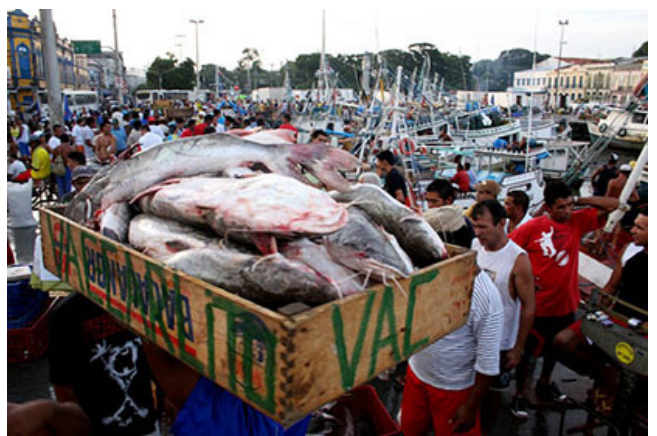

Fonte: https://expodoslados.wordpress.com/page/2/ concorrência por segmentos de economia criativa ou de busca do bem viver, fomentada por investimentos públicos e oferta de qualidade de vida (Hall, 2014).

Durante a maior parte desse mesmo período (meados dos anos 1970 e anos 1980), houve outro movimento nas cidades dos países do Sul, o da concorrência para receber indústrias clássicas ou para assumir uma posição na rede mundial a partir do potencial turístico (de lazer, negócios ou eventos) (Hall e Pfeiffer, 2000). No caso de Belém, em um primeiro momento, observou-se ligeira ação de industrialização no município vizinho de Barcarena, criação de distritos industriais que não deslancharam em Belém e Ananindeua e um fortalecimento das atividades de comércio e serviço decorrentes das ações do grande capital e do Governo Federal, pulverizadas pelo interior do estado (Cardoso e Lima, 2015). Recentemente, as cidades amazônicas têm pleiteado a instalação de parques de ciência e tecnologia, na expectativa de atração de instituições e pesquisadores interessados na pesquisa de ativos amazônicos (biodiversidade)
(CGEE, 2009), novamente, recorrendo, quando muito, à adaptação seletiva de espaços para melhorar a oferta de condições de vida desse público-alvo, na esteira do processo de produção de novas áreas pelo setor imobiliário, que na última década assumiu tais cidades como locais privilegiados para investimentos, em face das maiores oportunidade de acumulação primitiva que estas oferecem, quando comparadas às metrópoles e cidades brasileiras de outras regiões, onde há maior incidência de um espaço intraurbano, e ele é mais organizado (Brasil, 2007).

Nos países do Norte, a redução de estruturas de planejamento, a flexibilização de normas e a negociação entre setores público e privado ocorreram em uma correlação de forças equilibrada pelas formas de organização social estabelecidas desde a fase industrial, pelo acúmulo de serviços e infraestrutura decorrentes de décadas de existência de um estado de bem-estar social (Hall, 1998). No contexto amazônico, a chegada de novas possibilidades produtivas ou da referência à simplificação da ação de planejamento chega 
sem nenhuma dessas credenciais. Ainda não houve mínima estruturação técnica para que a administração pública desenvolvesse as propostas e se apropriasse dos instrumentos de planejamento disponibilizados pela legislação federal, passíveis de serem utilizados quando houvesse interesse de ação coordenada entre os setores público e privado.

Observa-se em outras orlas de Belém e Ananindeua (orla do Rio Arari, por exemplo; ver Figuras 19 e 20), nas quais o setor imobiliário vem atuando de modo semelhante ao combatido no Lago Paranoá (em Brasília), sem que haja nenhuma atenção ou reclamação. A discussão colocada de forma muito sedutora para tornar o centro histórico de Belém um espaço turístico de apelo internacional afetará todo o perímetro de orla do município de Belém, para suas mais de quarenta ilhas, e as tantas orlas das cidades do interior do Pará, em um efeito dominó. Por

Figura 19 - Condomínio na margem do rio Ariri

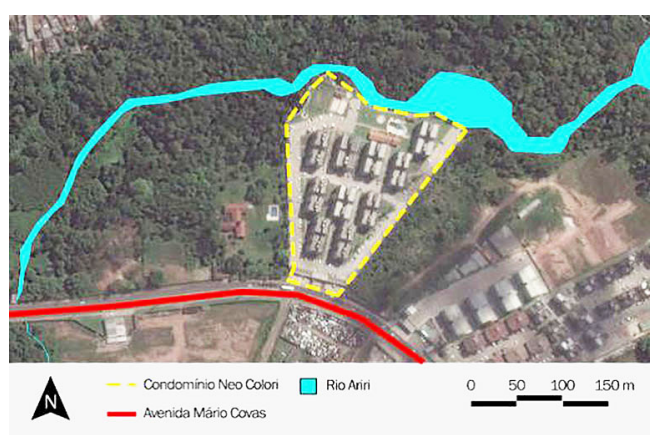

Fonte: Elaboração de Patrick Rocha a partir de imagem do Google Earth, 2016. isso, há de se ter cuidado com a explicitação de seus posicionamentos filosóficos e as formas de operação.

Diante do exposto, é evidente que existe uma lógica ou um "projeto" para Belém, baseada(o) em concepções importadas, que não são necessariamente boas ou ruins, mas que, nesse caso particular, conta com a intenção de distanciamento e ruptura em relação às matrizes populares. Contudo, ainda há tempo de reexaminar essa plataforma à luz das recomendações de Santos (1979) sobre as necessidades de articulação entre os circuitos superior e inferior da economia, para que haja desenvolvimento em contextos periféricos, sujeitos às modernizações seletivas, de modo que a internacionalização possível não seja predatória e ocorra em favor do que é genuíno do urbano amazônico, especialmente da sociobiodiversidade.
Figura 20 - Renderização do Condomínio

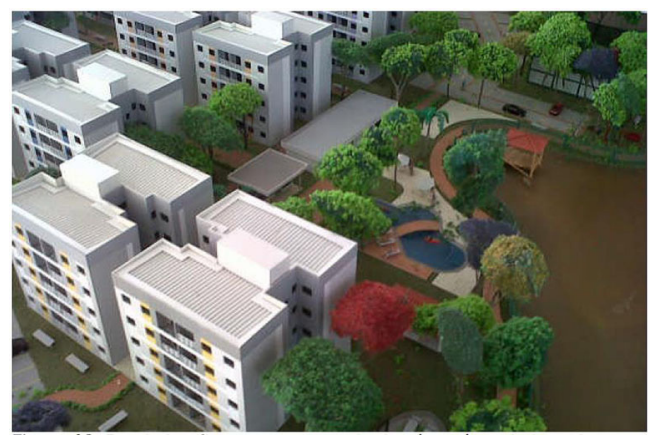

Fonte: rodrigobrasilbrokers.blogspot.com.br/2011/11/neocolori.html 
Nessa via, é importante destacar um movimento constituído por artistas, artesãos, profissionais liberais e estudantes, que busca se articular à matriz popular através do fomento de uma rede de economia solidária e criativa e da valorização da identidade local, com o resgate de manifestações tradicionais e culturais. É criado um ambiente de "festa", mas também de resistência à "disneyficação" ou transformação do espaço para fins exclusivamente turísticos. Tão importantes quanto as intervenções físicas, que alimentam a especulação imobiliária, são as iniciativas intensivas em pessoas, tais como o Projeto Circular (ver Figura 21), que, ao partir de uma agenda de eventos, constitui oportunidade efetiva de aproximação dos circuitos superior e inferior da economia urbana, ao dar sentido para aquele que talvez seja o eixo central da proposta de cidade criativa para 0 contexto urbano amazônico: o espaço de tolerância, de valorização da diversidade, de participação coletiva, da festa (e não do espetáculo) e da cidade vivida, como lócus de emancipação e cidadania.

Figura 21 - Mapa com os lugares que participam do Projeto Circular.

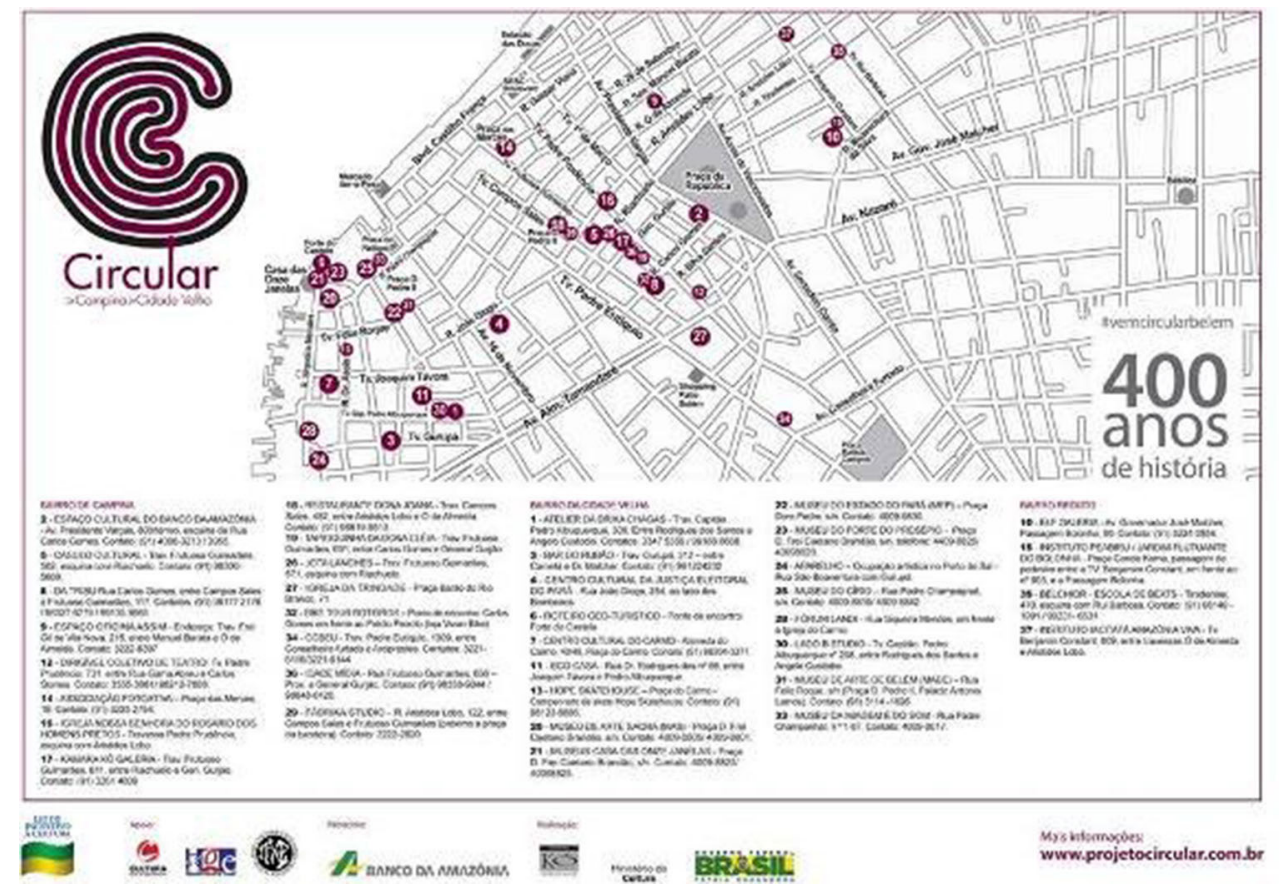

Fonte: www.projetocircular.com.br 
Espera-se, com esse documento, ter lançado elementos para aprofundamento do debate com foco em prioridades, sinergias e parcerias. 0 que mais importa, no caso do conjunto arquitetônico do Ver-o-Peso, são as obras físicas ou as estruturas sociais? $\mathrm{Ou}$ como adicionar camadas técnicas que melhorem os usos historicamente bem-sucedidos na área em discussão, aproveitando quem já vive e trabalha no lugar, suas experiências e capacidade criativa? Além disso, o que é mais defensável, do ponto de vista coletivo: o fortalecimento das formas de apropriação da paisagem e dos espaços públicos ou a mercadificação das orlas e dos espaços verdes? Em última análise, para que investimentos públicos devem acontecer? Para a melhoria da vida cotidiana das pessoas do lugar ou para a produção do espaço artificial e espetacularizado de deleite do visitante, sob o preço da alienação e subordinação de grupos sociais locais?

\section{Ana Cláudia Duarte Cardoso}

Universidade Federal do Pará, Faculdade de Arquitetura e Urbanismo, Programas de Pós-Graduação em Arquitetura e Urbanismo e em Economia. Belém, PA/Brasil.

aclaudiacardoso@gmail.com

\section{Taynara do Vale Gomes}

Universidade Federal do Pará, Faculdade de Arquitetura e Urbanismo, Programa de Pós-Graduação em Arquitetura e Urbanismo. Belém, PA/Brasil.

taynaragomes@gmail.com

\section{Ana Carolina Campos de Melo}

Universidade Federal do Pará, Programa de Pós-Graduação em Economia. Belém, PA/Brasil. carolmelo08@gmail.com

\section{Luna Barros Bibas}

Universidade Federal do Pará, Faculdade de Arquitetura e Urbanismo, Programa de Pós-Graduação em Arquitetura e Urbanismo. Belém, PA/Brasil.

Ibbibas@gmail.com 


\section{Notas}

(1) Sobre a reportagem alusiva à criação do Centro Global de Gastronomia e Biodiversidade da Amazônia, acessar o link http://www.agenciapara.com.br/noticia.asp?id_ver=118484.

(2) Sobre o título de Cidade Criativa da Gastronomia recebido por Belém, acessar o link http:// g1.globo.com/pa/para/noticia/2015/12/belem-e-eleita-cidade-criativa-da-gastronomia-pelaunesco.html.

(3) Sobre a revitalização de novos galpões do Porto de Belém com sua integração a equipamentos já existentes e transformação de uso de prédios históricos próximos, acessar o link http://www. diarioonline.com.br/noticias/para/noticia-365192-helder-lanca-projeto-de-revitalizacao-doporto.html.

(4) Todo esse debate também é de interesse para a área existente entre o Portal da Amazônia e a Cidade Universitária, visto que está em curso, na região, uma ação de macrodrenagem que duplicará a Avenida. Bernardo Sayão, que conta com uma faixa de áreas da União ocupada com grandes usos entre a avenida e o rio Guamá, que tenderão a ser substituídos por usos mais nobres silenciosamente se não houver debate público sobre o projeto estratégico subjacente para toda essa área.

(5) Borja e Castells usam como exemplo de líder empreendedor carismático Pasqual Maragall, responsável pela modernização de Barcelona para os jogos Olímpicos de 1992, figura política que ocupou outras comissões importantes na Comunidade Europeia e na Rede Internacional de Gestores de Regiões e Prefeitos.

\section{Referências}

ARAÚJO, D.; SOUZA, C.e RODRIGUES, D. (2015). “A metrópole Belém na transição econômica: estrutura produtiva e mercado de trabalho". In: CARDOSO, A. e LIMA, J. (orgs.). Belém: transformações na ordem urbana. Rio de Janeiro, Letra Capital.

BELÉM (1994). Lei no 7.709, de maio de 1994. Dispõe sobre a preservação e proteção do Patrimônio Histórico, Artístico, Ambiental e Cultural do Município, o Centro Histórico de Belém.

(1999). Lei Complementar de Controle Urbanístico $n^{\circ} 2 / 1999$. Dispõe sobre a política de desenvolvimento e expansão urbana do Município.

(2002). Revitalização da orla de Belém: plano conceitual. Belém, Secretaria Municipal de Coordenação Geral do Planejamento e Gestão, Technum consultoria.

BELÉM, Prefeitura Municipal (2016a). Decreto municipal no 84986, de 16 de fevereiro de 2016. Belém. (2016b). Decreto municipal no 84927, de 3 de fevereiro de 2016. Belém.

BRASIL (2007). Assentamentos precários no Brasil Urbano. Eduardo Marques/ Ministério das Cidades (org.). Brasília, Mcidades. 
BORJA, J. e CASTELLS, M. (1996). As cidades como atores políticos. Novos Estudos Cebrap, n. 45, pp. 152-166.

CARDOSO, A. e LIMA, J. (orgs.) (2015). Belém: transformações na ordem urbana. Rio de Janeiro, Letra Capital.

CARVALHO, L.; LIMA, D. e LEITÃO, W. (orgs.) (2010). Inventário de Referências Culturais do Ver-o-peso. Belém, Associação das Erveiras e Erveiros do Ver-opeso/Petrobrás/MINC- IPHAN. (Mimeo).

CGEE (2009). Um projeto para a Amazônia no século 21: desafios e contribuições. Brasília, DF, Centro de Gestão e Estudos Estratégicos.

COSTA, F. (2009). Trajetórias tecnológicas como objeto de política de conhecimento para a Amazônia: uma metodologia de delineamento. Revista Brasileira de Inovação, v. 8, n. 1, pp. 35-56.

FLORIDA, R. (2010). O grande recomeço: as mudanças no estilo de vida e de trabalho que podem levar à prosperidade pós-crise. Rio de Janeiro, Elsevier.

FURTADO, G. e ALVES, S. (2012) Cidades criativas em Portugal e o papel da arquitetura. Revista Crítica de Ciências Sociais. Coimbra, v. 1, n. 99, pp. 125-140.

GLAESER, L (2011). Os centros Urbanos: a maior invenção da humanidade. São Paulo, Elsevier.

HALL, P. (1998). Cidades do Amanhã. São Paulo, Perspectiva.

(2014). Good Cities, Better Lives: How Europe Discovered the Lost Art of Urbanism. Londres, Routledge.

HALL, P. e PFEIFFER, U. (2000). Urban future 21: a global agenda for the twenty-first century. Londres, E\&FN Spon, pp. 3-140

HARVEY, D. (2011). O enigma do Capital. São Paulo, Boitempo.

MENDES, L. (2012). Nobilitação urbana marginal enquanto prática emancipatória: Alternativa ao discurso hegemónico da cidade criativa? Revista Crítica de Ciências Sociais. Coimbra, v. 1, n. 99, pp. 51-72.

PRATT, A. (2010). Creative cities: Tensions within and between social, cultural and economic development. City, Culture And Society, [s.I.], v. 1, n. 1, pp.13-20. Elsevier BV. Disponível em: http://dx.doi.org/10.1016/j.ccs.2010.04.001.

SANTOS, M. (1979). O espaço dividido. São Paulo. Francisco Alves.

SHUMPETER, J. (1988). A teoria do desenvolvimento econômico: uma investigação sobre lucros, capital, credito, juro e o ciclo econômico. São Paulo, Nova Cultural.

SILVA, H. (2015), "Cidades, urbanização, desenvolvimento na Amazônia: notas para uma interpretação lefebvriana". In: COSTA, G.; COSTA, H. e MONTE-MÓR, R. Teorias e Práticas Urbanas, condições para a sociedade urbana. Belo Horizonte, C/Arte.

VAINER, C. (1999). Pátria, empresa e mercadoria: notas sobre a estratégia discursiva do planejamento estratégico urbano. In: VIII ENCONTRO NACIONAL DA ANPUR. Anais. Porto Alegre, Anpur.

Texto recebido em 29/abr/2016

Texto aprovado em 24/ago/2016 